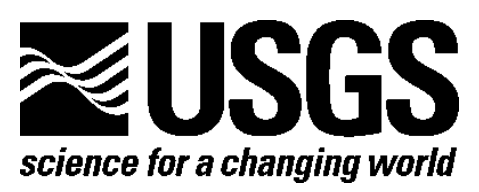

\title{
Soils, Vegetation, and Woody Debris Data from the 2001 Survey Line Fire and a Comparable Unburned Site, Tanana Flats Region, Alaska
}

By K.L. Manies, J.W. Harden, and T.N. Hollingsworth

Open-File Report 2014-1049

U.S. Department of the Interior U.S. Geological Survey 


\section{U.S. Department of the Interior \\ SALLY JEWELL, Secretary}

\section{U.S. Geological Survey \\ Suzette M. Kimball, Acting Director}

U.S. Geological Survey, Reston, Virginia: 2014

For product and ordering information:

World Wide Web: http://www.usgs.gov/pubprod/

Telephone: 1-888-ASK-USGS

For more information on the USGS-the Federal source for science about the Earth, its natural and living resources, natural hazards, and the environment: World Wide Web: http://www.usgs.gov/

Telephone: 1-888-ASK-USGS

Suggested citation:

Manies, K.L., Harden, J.W., and Hollingsworth, T.N., 2014, Soils, vegetation, and woody debris data from the 2001 Survey Line fire and a comparable unburned site, Tanana Flats region, Alaska: U.S. Geological Survey Open-File Report 2014-1049, 36 p., http://dx.doi.org/10.3133/ofr20141049.

ISSN 2331-1258 (online)

Any use of trade, product, or firm names is for descriptive purposes only and does not imply endorsement by the U.S. Government.

Although this report is in the public domain, permission must be secured from the individual copyright owners to reproduce any copyrighted material contained within this report 


\section{Contents}

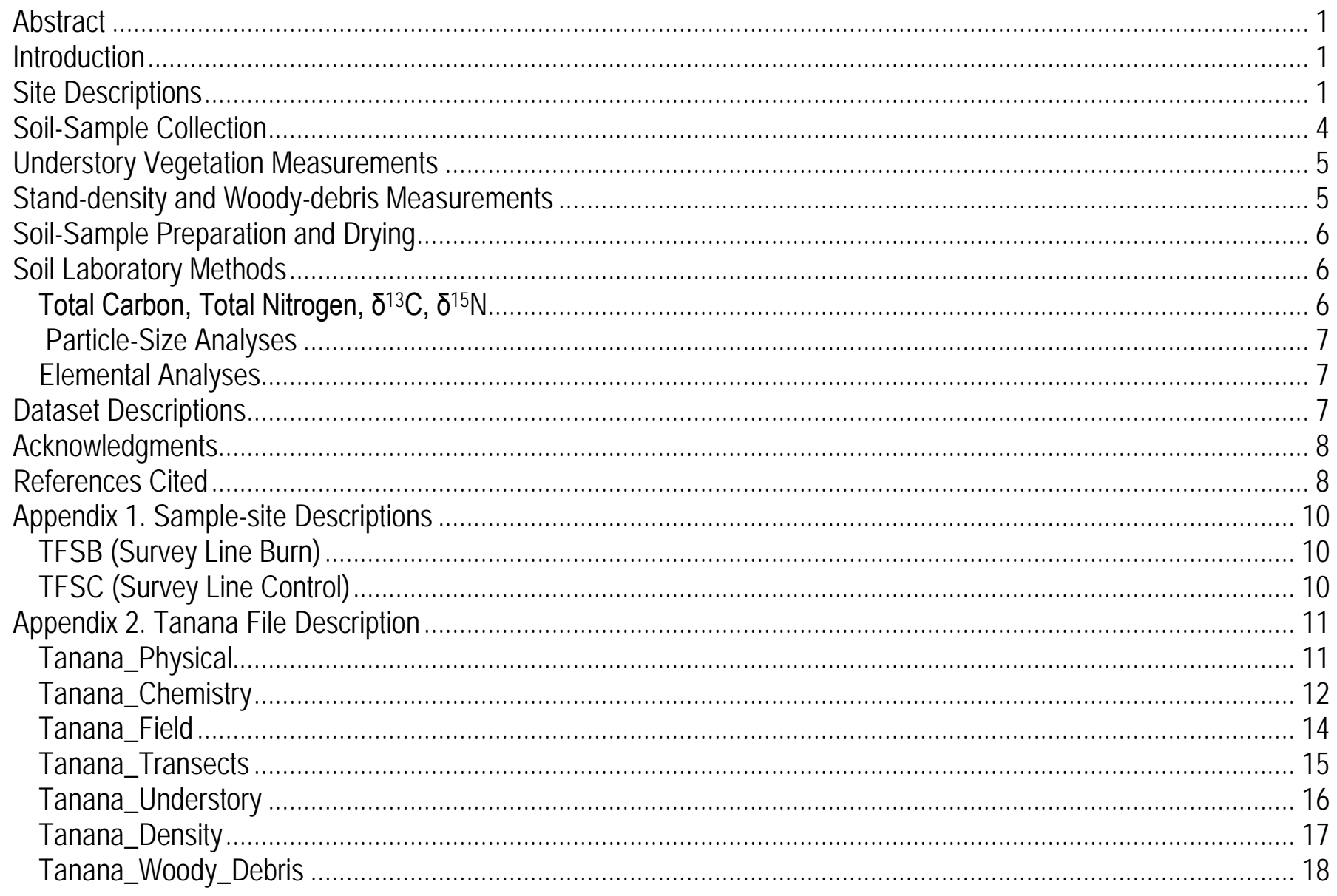

The tables described in Appendix 2 can be downloaded at: http://pubs.usgs.gov/of/2014/1043 


\section{Figures}

Figure 1. The location of the two study sites along the Tanana River. TFSB is the Survey Line burn site. TFSC is the control site. 2

Figure 2. A photograph of the Tanana Flats Survey Line burn (TFSB) site, taken in August of 2002 (slightly over

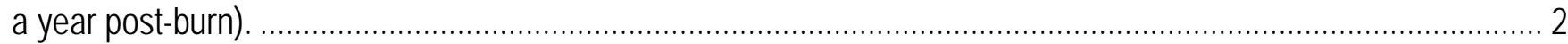

Figure 3. A photograph of Tanana Flats Survey Line control (TFSC) site. The flagging marks a $1 \mathrm{~m}^{2}$ plot used to determine vegetation cover.

\section{Tables}

Table 1. Values ( $\mathrm{kg} / \mathrm{hectare}$ ) for fine $(<7 \mathrm{~cm}$ diameter) and coarse $(\geq 7 \mathrm{~cm}$ diameter) woody debris. Aboveground and belowground debris is material that is $<50 \%$ or $\geq 50 \%$ covered by organic soil, respectively. ...... 5 Table 2. Summary of stand density values (trees/hectare) for trees $>3$ and $<3 \mathrm{~m}$. BS $=$ black spruce, $\mathrm{TA}=$

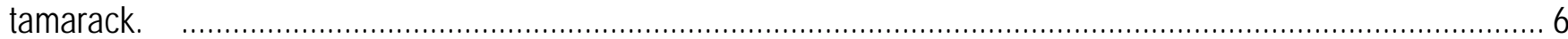

Table 3. Statistics of analyses for working standards run on the IRMS from 2001 through 2008 ..................... 7 


\section{Conversion Factors}

Sl to Inch/Pound

\begin{tabular}{lll}
\hline \multicolumn{1}{c}{ Multiply } & By & To obtain \\
\hline centimeter $\left(\mathrm{cm}=10^{-3} \mathrm{~m}\right)$ & Length & \\
meter $(\mathrm{m})$ & 0.3937 & inch (in.) \\
meter $(\mathrm{m})$ & 3.281 & foot (ft) \\
\hline & 1.094 & yard (yd) \\
\hline square meter $\left(\mathrm{m}^{2}\right)$ & Area & \\
\hline & 10.76 & square foot $\left(\mathrm{ft}^{2}\right)$ \\
\hline gram $(\mathrm{g})$ & Mass & \\
kilogram $\left(\mathrm{kg}=10^{3} \mathrm{~g}\right)$ & 0.03527 & Ounce $(\mathrm{oz})$ \\
\hline
\end{tabular}




\title{
Soils, Vegetation, and Woody Debris Data from the 2001 Survey Line Fire and a Comparable Unburned Site, Tanana Flats Region, Alaska
}

By Kristen L. Manies ${ }^{1}$, Jennifer W. Harden ${ }^{1}$ and Teresa N. Hollingsworth²

\begin{abstract}
This report describes the collection and processing methodologies for samples obtained at two sites within Interior Alaska: (1) a location within the 2001 Survey Line burn, and (2) an unburned location, selected as a control. In 2002 and 2004 U.S. Geological Survey investigators measured soil properties including, but not limited to, bulk density, volumetric water content, carbon content, and nitrogen content from samples obtained from these sites. Stand properties, such as tree density, the amount of woody debris, and understory vegetation, were also measured and are presented in this report.

\section{Introduction}

The Survey Line fire (B247) burned more than 45,000 hectares within the Tanana River floodplain, Alaska. Ignition was in late June of 2001, and the fire was declared out in the fall. This fire burned a variety of ecosystem types, including open black spruce [Picea mariana (Mill.) BSP] forest and wetter tussock-dominated systems. Fire affects carbon (C) storage of these ecosystems both directly (for example, fire emissions, loss of vegetation) and indirectly. Indirect effects include altering the soil temperature regime through changes in albedo and the loss of organic layers, which play an important role in soil insulation (O’Neill and others, 2002). Changes in soil temperature in turn affect decomposition rates (Wickland and others, 2010) and vegetative regrowth (Johnstone and others, 2010). To understand these effects, U.S. Geological Survey (USGS) investigators studied two forested sites, one that had burned and an unburned control. Other studies based on the Survey Line fire include changes in post-fire active layer depth (Hollingsworth, 2007) and testing the ability of remotely sensed data to determine burn severity (Epting and others, 2005).
\end{abstract}

\section{Site Descriptions}

Both the burned and unburned sites were located in the Tanana Flats floodplain region; therefore, all sample names begin with the same two letters (TF), representing the region in which they were collected. The burn site was located within the perimeter of the Survey Line burn (TFSB), south of the Tanana River at $64.64692^{\circ} \mathrm{N}, 148.29767^{\circ} \mathrm{W}$ (WGS84 datum; fig. 1). A location near this site was classified as a moderate to moderately high burn severity by using the Composite Burn Index (Verbyla, 2007). Although much of the ground remained charred within the burn site at the time of

\footnotetext{
${ }^{1}$ U.S. Geological Survey.

${ }^{2}$ U.S. Department of Agriculture, Forest Service.
} 
sampling (spring and summer of 2002), there was recruitment of new vegetation, including, but not limited to, Calamagrostis canadensis, Ditrichum sp., Eriophorum vaginatum, Ledum groendlandicum, Betula sp., and Vaccinium uligonosum (fig. 2).

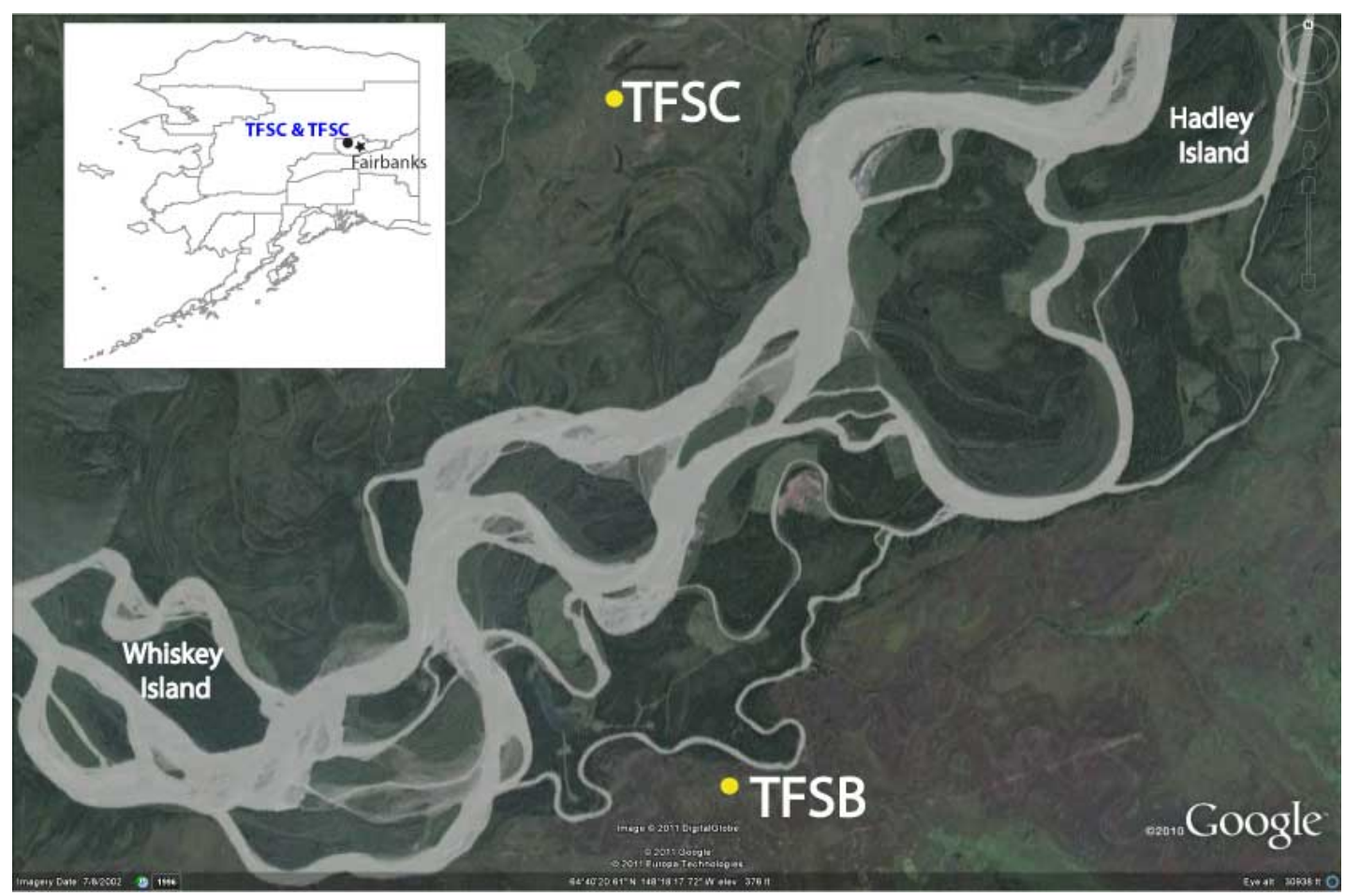

Figure 1. The location of the two study sites along the Tanana River, Alaska. TFSB is the Survey Line burn site. TFSC is the control site.

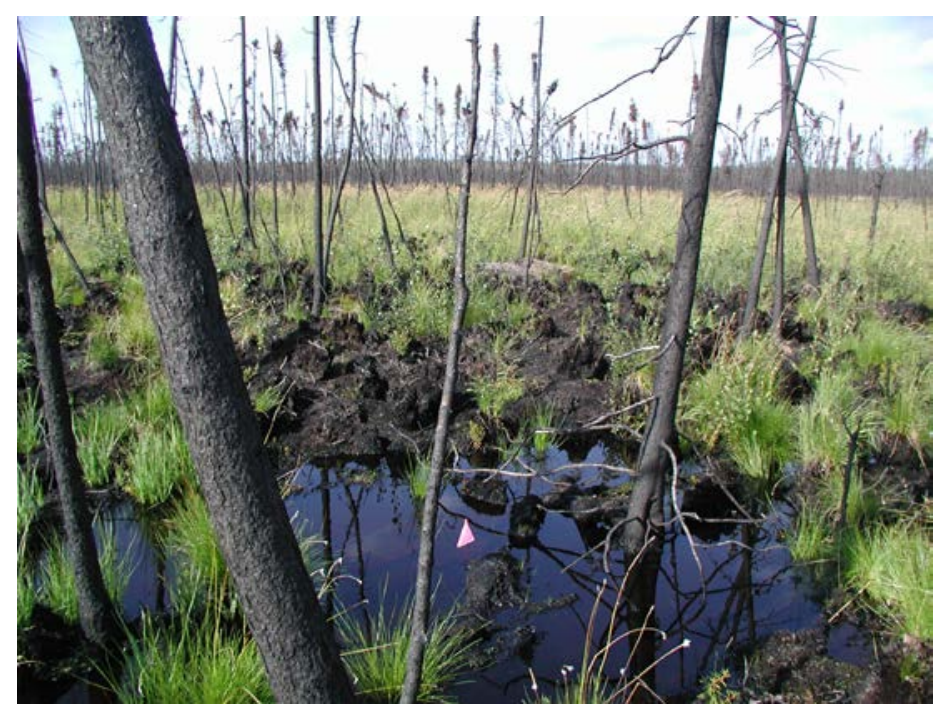

Figure 2. A photograph of the Tanana Flats Survey Line burn (TFSB) site, Tanana Flats region, Alaska, taken in August of 2002 (slightly more than a year post-burn). 


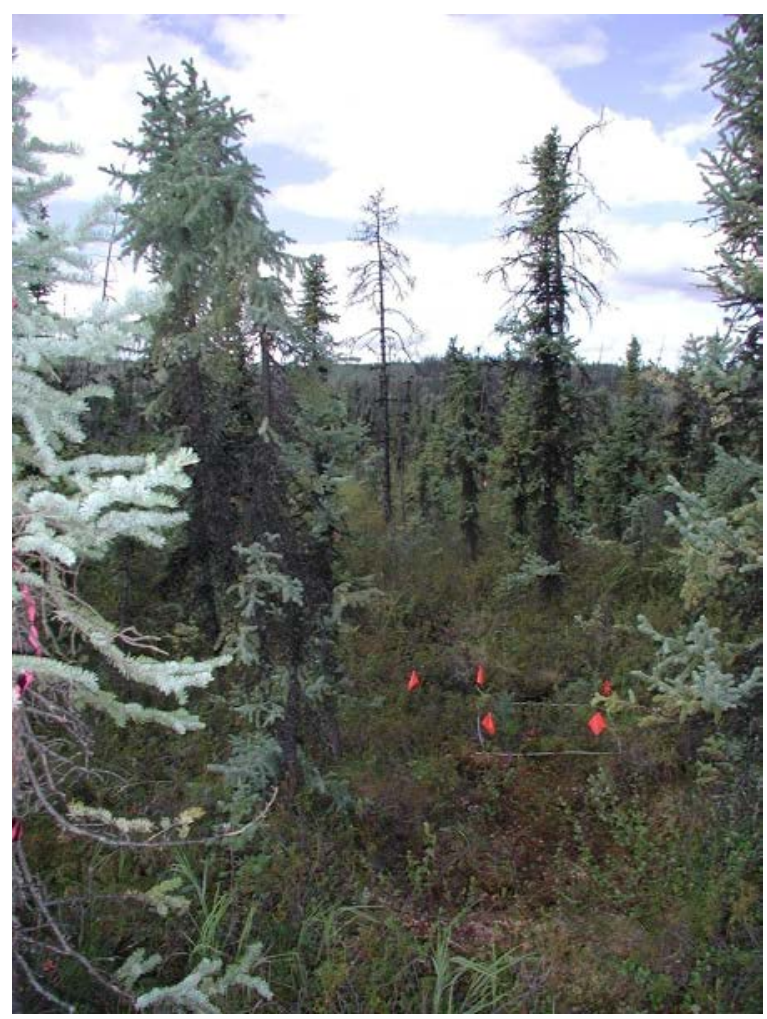

Figure 3. A photograph of Tanana Flats Survey Line control (TFSC) site, Tanana Flats region, Alaska. The flagging marks a $1 \mathrm{~m}^{2}$ plot used to determine vegetation cover.

The control site (TFSC) was located north of the Tanana River within the Bonanza Creek Experimental Forest, part of the Bonanza Creek Long-Term Ecological Research (LTER) program (fig. 1, appendix 1). TFSC is located at lat $64.69744^{\circ}$ N., long $148.31917^{\circ} \mathrm{W}$. (NAD83 ${ }^{\ddagger}$ datum) and was sampled in the spring of 2002 and the summer of 2004. This site was also used for a study of the role of drainage on $\mathrm{CO}_{2}$ and $\mathrm{CH}_{4}$ exchange (Wickland and others, 2010). The vegetation is similar to TFSB, with the addition of tamarack (Larix laricina) and Sphagnum sp. (fig. 3).

Each site was visited two times, once in the late spring of 2002 to scout for sites and once at a later date for more intense soil sampling. During the first visit, one or more cores were taken at random locations within the general location of the site. On the subsequent sampling visit, perpendicular transects (in the shape of an ' $L$ ') were marked (typically with pink/black flagging). Along each transect, points were marked every $10 \mathrm{~m}$. Soil descriptions and (or) samples were taken at these locations. All soil cores were processed similarly, regardless of when they were obtained. Vegetation measurements (TFSB site only) were also tied to the points along each transect. GPS locations and more detailed information regarding these sampling locations can be found in appendix 1.

\footnotetext{
FThis report lists the datum used to collect the GPS coordinates, but for the level of precision used here it should be noted that the WGS84 and NAD83 datum are equal. In other words, if the alternate datum is used, the location would only be off by several feet.
} 


\section{Soil-Sample Collection}

At each site we dug soil pits and described soil horizons, following U.S. Department of

Agriculture's Natural Resource Conservation Service (USDA-NRCS) (Staff, 1998) and Canadian (Committee, 1998) methodologies. We modified horizon codes according to the following scheme:

$\mathrm{L} \quad$ Live moss, which is green and generally contains some leaf and needle litter.

D Dead moss, which is composed of undecomposed or slightly decomposed dead moss. This layer is characterized by fibric organic horizons that contain more moss than roots. This layer would be considered an $\mathrm{O}_{\mathrm{i}}$ horizon (U.S. soil system).

F Fibric (Canadian soil system) or fibrous organic layers, which vary in degree of decomposition, but in which roots are more abundant than recognizable moss parts. Most of these layers would be considered $\mathrm{O}_{\mathrm{i}}$ horizons (U.S. soil system), or upper duff [U.S. Forest Service (USFS) system].

M Mesic (Canadian soil system) organic layers, which are moderately decomposed, with few, if any, recognizable plant parts other than roots. These layers are generally considered $\mathrm{O}_{\mathrm{e}}$ horizons (U.S. soil system) or lower duff layers (USFS system).

$\mathrm{H} \quad$ Humic (Canadian soil system) or sapric organic layers, which are highly decomposed. These layers generally smear upon squeezing and contain no recognizable plant parts. H layers are generally considered $\mathrm{O}_{\mathrm{a}}$ horizons (U.S. soil system) or lower duff (USFS system).

A Mineral soil that forms at the surface or below organic-soil horizons (U.S. and Canadian soil systems), containing less than 20 volume percent organic matter, as judged in the field.

B Mineral soil that has formed below an A horizon (U.S. and Canadian soil systems), with little or none of its original lithologic structure.

C Mineral soil that has been little affected by pedogenic processes (U.S. and Canadian soil systems).

LT Litter layer (dead leaves, twigs).

Se Sedge.

WD Wood.

Horizon codes could be further described with a lowercase 'b', designating that the horizon had been burned, indicating anything from light scorching to deep charring, or an ' $\mathrm{f}$ ', indicating that the horizon was frozen at the time of sampling. In general, soil was excavated to the depth of mineral soil; however, we were unable to reach mineral soil consistently at site TFSC, instead stopping once the soil was frozen, due to the early sampling date.

Each soil horizon was labeled with two numbers representing the soil-profile number and basal depth of the sample (in centimeters). A decimal point separates the profile number from the basal depth; for example, TFSB 3.19 denotes a sample from the Tanana Flats Survey Line fire burn site, profile 3, with a basal depth of $19 \mathrm{~cm}$.

A subset of soil profiles was not only described, but also sampled by soil horizon. Samples were collected for bulk-density measurements, analytical purposes, and determination of moisture content. Samples were collected by either cutting out an area of known volume, or by using a corer of known volume (either a Makita corer, see Nadler and Wein (1998), or a SIPRE corer). Samples were placed in clean Ziploc bags or tins and shipped soon after collection to the USGS laboratory in Menlo Park, California. 


\section{Understory Vegetation Measurements}

At the Survey Line burn site (TFSB) a temporary plot was anchored to each point along the site's transects to measure percentage of cover of the understory vegetation. These plots were $120 \mathrm{~cm}^{2}$. Percentage of cover was quantified visually and assigned into one of eight categories: $<1,1-2,2-5,5-$ 10, 10-25, 25-50, 50-75, or 75-100 percent (Hollingsworth and others, 2006).

\section{Stand-density and Woody-debris Measurements}

Downed woody debris was measured by using the line-intersect method (Brown, 1974; Harmon and Sexton, 1996). Eighteen to twenty 20-m transects were located at each site. Fine woody debris $(<7$ $\mathrm{cm}$ diameter) was tallied into one of five size classes (diameters of 0.0-0.49, 0.50-0.99, 1.0-2.99, 3.04.99, and 5.0-6.99 cm) and its location was classified as either above ground or below ground $(<50$ or 50-99 percent buried by forest floor organic matter, respectively). For coarse woody debris ( $\geq 7 \mathrm{~cm}$ diameter), species, diameter $(\mathrm{cm})$ at transect intersection, and decay class were also recorded. Data were converted to mass of wood per unit of ground area by using Nalder and others (1999) formulas and fuel-load multipliers (based on species and size class) for Southern Northwest Territories (black spruce) and Central Saskatchewan (tamarack). A summary of the findings can be found in table 1.

Stand density was measured by using the point-center quarter (PCQ) method (Cottam and Curtis, 1956) for trees $>3 \mathrm{~m}$ tall. The PCQ method records the distance of the closest tree in each of the four quadrants surrounding a point. These data are converted to density by first computing the mean area (MA) of the four trees:

$$
\left.M A=\left[\left(\sum d_{i}\right) / n\right) / c\right]^{2}
$$

where $M A$ is the mean area per tree $\left(\mathrm{m}^{2} /\right.$ tree $), d_{i}$ is the distance $(\mathrm{m})$ of the tree $i$ from the center point, $n$ is the number of trees, and $c$ is a correction factor based on the number of trees per point ( 4 trees $=1.00$ ). Overall density at the point is then calculated by using:

$$
D=(1 / M A) *\left(1,000 \mathrm{~m}^{2} / \mathrm{ha}\right),
$$

where $D$ is the relative density (trees/ha) and $M A$ is mean area $\left(\mathrm{m}^{2} /\right.$ tree). Density of trees $<3 \mathrm{~m}$ tall were measured using a $2 \mathrm{~m}$ circular plot centered around the same point used for the PCQ measurements. Tree species, diameter at breast height (also known as DBH, defined as diameter at $1.37 \mathrm{~m}$ ), diameter at the base, height to live (m), height to crown (m), and condition (live/dead) also were recorded for all trees. A summary of the findings can be found in table 2 .

Table 1. Values for fine ( $<7 \mathrm{~cm}$ diameter) and coarse $(\geq 7 \mathrm{~cm}$ diameter) woody debris, Tanana Flats, Alaska.

[Above- and below-ground debris is material that is $<50$ percent or $\geq 50$ percent covered by organic soil, respectively.]

\begin{tabular}{|c|c|c|c|c|c|}
\hline & \multicolumn{5}{|c|}{ Woody debris (kg/ha): } \\
\hline & \multicolumn{2}{|c|}{ Fine debris $(<7 \mathrm{~cm})$} & \multicolumn{2}{c|}{ Coarse debris $(>=7 \mathbf{c m})$} & \\
Site & $\begin{array}{l}\text { Above- } \\
\text { ground }\end{array}$ & Below- ground & $\begin{array}{l}\text { Above- } \\
\text { ground }\end{array}$ & Below- ground & Total \\
\hline TFSB & 3216 & 86 & 845 & 0 & 4147 \\
\hline TFSC & 159 & 0 & 0 & 0 & 159 \\
\hline
\end{tabular}


Table 2. Summary of stand density values for trees $>3$ and $<3 \mathrm{~m}$, Tanana Flats, Alaska.

[BS, black spruce; TA, tamarack.]

\begin{tabular}{|c|l|c|c|c|c|c|c|}
\hline \multirow{2}{*}{ Site } & $\begin{array}{l}\text { Height } \\
(\mathbf{m})\end{array}$ & \%BS & \%TA & \% live & $\begin{array}{c}\text { Average density } \\
\text { (tree/ha) }\end{array}$ & Stdev & N \\
\hline \multirow{2}{*}{ TFSC } & $>3$ & 53 & 47 & 54 & 1965 & 1839 & 17 \\
\cline { 2 - 8 } & $<3$ & 41 & 41 & 90 & 7256 & 4256 & 17 \\
\hline \multirow{2}{*}{ TFSB } & $>3$ & 100 & 0 & 0 & 1270 & 2092 & 20 \\
\cline { 2 - 8 } & $<3$ & 98 & 2 & 0 & 2069 & 2522 & 20 \\
\hline
\end{tabular}

\section{Soil-Sample Preparation and Drying}

Upon the arrival of samples at the USGS laboratory, samples were inventoried using the field sheets. Any discrepancy between field descriptions and laboratory observations was resolved before sample preparation began. All samples were placed on open shelves in an isolated room and allowed to air-dry to a constant weight, as determined by weights measured at least one week apart. Temperature during air-drying ranged from $20^{\circ} \mathrm{C}$ to $30^{\circ} \mathrm{C}$. After air-drying, samples were oven-dried for 48 hours in a forced-draft oven. Samples that were classified as organic-soil horizons (for example, moss, litter) were oven-dried at $65^{\circ} \mathrm{C}$ to avoid loss or alteration of organic matter by oxidation or decomposition. The remaining samples were oven-dried at $105^{\circ} \mathrm{C}$.

After oven-drying, samples were thoroughly mixed and split into subsamples for analysis and archiving. (Archive fractions of most of the samples described here are available by contacting $\mathrm{J}$. Harden at the U.S. Geological Survey in Menlo Park, Calif.). Samples were then processed in one of two ways, depending on horizon code. Mineral-soil samples were gently crushed using a mortar and pestle, with care to break only aggregates, and then sieved through a 2-mm screen. Soil particles that did not pass through the screen were removed, weighed, and saved separately; soil that passed through the screen was then ground by using a mortar and pestle to pass through a 60 -mesh $(0.246-\mathrm{mm})$ screen. The ground material was mixed and placed in a labeled glass sample bottle for subsequent analyses.

Organic samples were weighed, and roots wider than $1 \mathrm{~cm}$ in diameter were removed, weighed, and saved separately. The remaining sample was then milled in an Udy Corp. (Fort Collins, Colo.) Cyclone mill to pass through a $0.5-\mathrm{mm}$ screen. The milled sample was thoroughly mixed, and a representative sample was placed in a labeled glass sample bottle for analytical chemistry.

\section{Soil Laboratory Methods}

\section{Total Carbon, Total Nitrogen, $\delta^{13} \mathrm{C}, \delta^{15} \mathrm{~N}$}

Because carbonates tend not to exist in the study area, nearly all of the $\mathrm{C}$ can be considered organic. A Carlo Erba NA1500 elemental analyzer coupled to a Micromass Optima isotope ratio mass spectrometer (IRMS) in continuous flow mode was used to determine total C, total Nitrogen (N), $\delta^{13} \mathrm{C}$, and $\delta^{15} \mathrm{~N}$. Samples were combusted in the presence of excess oxygen. The resulting sample gasses were swept in a continuous flow of helium through an oxidation furnace, followed by a reduction furnace, to yield $\mathrm{CO}_{2}, \mathrm{~N}_{2}$, and water vapor. Water was removed by a chemical trap, and $\mathrm{CO}_{2}$ and $\mathrm{N}_{2}$ were separated chromatographically before entering the Micromass Optima IRMS for the measurement of $\mathrm{C}, \mathrm{N}, \delta^{13} \mathrm{C}$, and $\delta^{15} \mathrm{~N}$. Carbon and $\mathrm{N}$ were determined by integrating the major ion peaks (mass 44 for $\mathrm{CO}_{2}$ and mass 28 for $\mathrm{N}_{2}$ ). For reliable quantification of $\delta^{15} \mathrm{~N}, 15-30 \mu \mathrm{g} \mathrm{N}$ are generally needed, and few samples met this criterion. Thus, the $\delta^{15} \mathrm{~N}$ data are not reported here; these data are available from the authors by 
request. The $\delta^{13} \mathrm{C}$ data are reported as deviations in parts per thousand (\%o) relative to a standard, here Vienna Pee Dee Belemnite (V-PDB). $\delta^{13} \mathrm{C}$ was calculated as:

$\delta^{13} \mathrm{C} \%$ o $=\left(\left(\left({ }^{13} \mathrm{C}\right.\right.\right.$ sample $/{ }^{12} \mathrm{C}$ sample $) /\left({ }^{13} \mathrm{C}\right.$ standard $/{ }^{12} \mathrm{C}$ standard $\left.\left.)\right)-1\right) * 1,000$.

All samples were calibrated using ethylenediamine tetra-acetic acid (EDTA). The chemical formula for this compound corresponds to a C content of 41.09 percent and a $\mathrm{N}$ content of 9.59 percent. Two working standards were analyzed as unknown samples in all runs to check consistency and overall precision: a marine sediment standard (MESS-1), issued by the Chemistry Division of the Canadian National Research Council, and a river sediment standard (NBS 1645), issued by the National Bureau of Standards, now the National Institute of Standards and Technology (NIST). Certified values were obtained from Govindaraju (1989). Measured values of these working standards for the IRMS that ran these samples are shown in table 3.

Table 3. Statistics of analyses for working standards run on the isotope ratio mass spectrometer, 2001-2008. [Certified values: MESS-1, 2.99 percent C; NBS-1645, 0.08 percent N; SRM-1547, 2.94 percent N]

\begin{tabular}{|l|c|c|c|c|c|c|c|c|c|}
\hline & \multicolumn{3}{|c|}{ \%C } & \multicolumn{3}{c|}{ \%N } & \multicolumn{3}{c|}{${ }^{13} \mathbf{C}$} \\
\hline Standard & Average & Stdev. & N & Average & Stdev. & N & Average & Stdev. & N \\
\hline MESS-1 & 3.02 & 0.15 & 49 & 0.18 & 0.01 & 49 & -25.64 & 0.14 & 49 \\
\hline NBS-1645 & 5.21 & 0.39 & 53 & 0.09 & 0.01 & 55 & -22.29 & 0.27 & 53 \\
\hline SRM-1547 & 46.57 & 2.00 & 398 & 2.83 & 0.15 & 389 & -26.81 & 0.30 & 134 \\
\hline
\end{tabular}

\section{Particle-Size Analyses}

A limited number of mineral-soil samples were selected for particle-size analyses. The laboratory of Dr. T. Fenton, Iowa State University, processed these samples by conventional pipette analyses (Walter and others, 1978). Owing to the large amounts of organic matter, some of the samples were washed in 35 percent hydrogen peroxide three times. Even after these treatments, some organic matter persisted, skewing the results toward overestimation of the sand fraction. The samples for which organic matter may have been problematic in particle size analyses are indicated in the Notes column of the Tanana_Physical file.

\section{Elemental Analyses}

Elemental concentrations within the samples were analyzed for 40 major, minor, and trace elements by using inductively coupled plasma-atomic emission spectrometry (ICP-AES). These samples were run by the USGS Research Chemistry Core Support, supervised by Paul Lamothe. Samples were ashed $\left(550{ }^{\circ} \mathrm{C}\right)$ and then pretreated with nitric acid and hydrogen peroxide and brought to dryness at low temperature (to help reduce the organic content and reduce reactivity). Samples were then digested using a mixture of hydrochloric, nitric, perchloric, and hydrofluoric acids at low temperatures. This final solution was introduced into the ICP-AES, where the elemental emission signals were measured simultaneously for the 40 elements. For more information regarding this procedure, calibration techniques, and its detection limits, see Briggs (2002).

\section{Dataset Descriptions}

Seven downloadable files contain the soil data collected from the sites described in this report. Appendix 2, Tanana File Descriptions, describes in more detail the data within the following Microsoft Excel files. 
- Tanana_Physical contains physical descriptions of the samples, such as volumetric field moisture, bulk density, and particle size.

- Tanana_Chemistry contains $\mathrm{C}, \mathrm{N}$, and $\delta^{13} \mathrm{C}$, and elemental analysis measurements for samples on which these analyses were run.

- Tanana_Field contains the field descriptions and height above mineral-soil values.

- Tanana_Transects contains descriptions for horizons within soil profiles that were not sampled (only described).

- Tanana_Vegetation includes the percentage of cover of different understory species found around the TFSB plots.

- Tanana_Density contains data pertaining to the trees measured for stand density (both PCQ and 2m plot methods).

- Tanana_Woody_Debris contains the data recorded for the woody-debris measurements.

\section{Acknowledgments}

We thank Jamie Hollingsworth for incredible support in getting to and from our burn site and for helping with sampling; Jennie Munster, Kim Wickland, and Emily Sampson for help with sampling; Marilyn Walker for her assistance in classifying the vegetation at the burn site. We also thank Brian Schmid of Iowa State University for processing samples for particle-size analysis and to Paul Lamothe for overseeing the elemental analyses. We would also like to thank Kim Perkins and Mark Waldrop for reviewing an earlier draft of this report. This work was supported by the Bonanza Creek Long-Term Ecological Research program (funded jointly by National Science Foundation Grant DEB-0423442 and USDA Forest Service, Pacific Northwest Research Grant PNW01-JV11261952-231) and by the USGS Global Change Program.

\section{References Cited}

Briggs, P.H., 2002, The determination of forty elements in geological and botanical samples by inductively coupled plasma-atomic emission spectrometry, in Taggart, Jr., J.E., ed., Analytical methods for chemical analysis of geologic and other materials, U.S. Geological Survey: U.S. Geological Survey Open File Report 02-223, p. G1-G18.

Brown, J.K., 1974, Handbook for inventorying downed woody material: U.S. Department of Agriculture Forest Service INT-16, 24 p.

Committee, Canadian Agricultural Services Coordinating, 1998, The Canadian system of soil classification (3rd edition ed.): Ontario, NRC Canada Research Press, 187 p.

Cottam, G., and Curtis, J.T., 1956, The use of distance measures in phytosociological sampling: Ecology, v. 37, no. 3, p. 451-460.

Damman, A.W.H., and French, T.W., 1987, The ecology of peat bogs of the glaciated Northeastern United States: A community profile: U.S. Fish and Wildlife Service 85(7.16), 100 p.

Epting, J., Verbyla, D., and Sorbel, B., 2005, Evaluation of remotely sensed indices for assessing burn severity in interior Alaska using Landsat TM and ETM+: Remote Sensing of Environment, v. 96, p. 328-339.

Govindaraju, K., 1989, Compliation of working value and sample description for 272 geostandards: Geostandards Newsletter, v. 13, p. 1-113.

Harmon, M.E., and Sexton, J., 1996, Guidelines for measurements of woody detritus in forest ecosystems: U.S. Long-Term Ecological Research Network Office U.S. Long-Term Ecological Research Publication No. 20, 73 p. 
Hollingsworth, J., 2007, Active layer depths: Survey Line Fire (2004-present), Bonanza Creek LongTerm Ecological Research: University of Alaska, Fairbanks. BNZ:240, accessed January 10, 2014, at http://www.lter.uaf.edu./data/detail.cfm?datafile_pkey=240.

Hollingsworth, T.N., Walker, M.D., Chapin, F.S., III, and Parsons, A.L., 2006, Scale-dependent environmental controls over species composition in Alaskan black spruce communities: Canadian Journal of Forest Research, v. 36, p. 1781-1796.

Johnstone, J.F., Hollingsworth, T.N., Chapin, F.S., III, and Mack, M.C., 2010, Changes in fire regime break the legacy lock on successional trajectories in Alaskan boreal forest: Global Change Biology, v. 16, p. 1281-1295.

Nadler, I.A., and Wein, R.W., 1998, A new forest floor corer for rapid sampling, minimal disturbance and adequate precision: Silva Fennica, v. 32, no. 4, p. 373-381.

Nalder, I.A., Wein, R.W., Alexander, M.E., and de Groot, W.J., 1999, Physical properties of dead and downed round-wood fules in the boreal forests of western and northern Canada.: International Journal of Wildland Fire, v. 9, no. 2, p. 85-99.

O'Neill, K.P., Kasischke, E.S., and Richter, D.D., 2002, Environmental controls on soil $\mathrm{CO}_{2}$ flux following fire in black spruce, white spruce, and aspen stand of interior Alaska: Canadian Journal of Forest Research, v. 32, p. 1525-1541.

Staff, S.S., 1998, Keys to soil taxonomy (8th ed.): Blacksburg, Va., Pocahontas Press, Inc., 599 p.

Verbyla, D., 2007, Fire severity estimates: 2001 Survey Line burn, Bonanza Creek Long-Term Ecological Research: University of Alaska, Fairbanks. BNZ:322, accessed January 10, 2014, at http://www.lter.uaf.edu./data/detail.cfm?datafile_pkey=322.

Walter, N.F., Hallberg, G.R., and Fenton, T.E., 1978, Particle size analysis by the Iowa State University Soil Survey Laboratory, in Hallberg, G.R., ed., Standard procedures for evaluation of Quaternary materials in Iowa.: Iowa City, Iowa, Iowa Geological Survey, p. 61-90.

Wickland, K.P., Neff, J.C., and Harden, J.W., 2010, The role of soil drainage class in carbon dioxide exchange and decomposition in boreal black spruce (Picea mariana) forest stands: Canadian Journal of Forest Research, v. 40, no. 11, p. 2123-2134.

Wickland, K.P., Striegl, R.G., Neff, J.C., and Sachs, T., 2006, Effects of permafrost melting on $\mathrm{CO}_{2}$ and $\mathrm{CH}_{4}$ exchange of a poorly drained black spruce lowland: Journal of Geophyiscal ResearchAtmospheres, v. 111, p. G02011. 


\section{Appendix 1. Sample-site Descriptions}

This appendix describes the locations of each site sampled within this report. The following text gives general directions to each site and explains how the sites were set up.

Each site was visited two times. The first visit was in the late spring of 2002 to scout for sites (the reconnaissance visit). At this time one or more cores were taken randomly within the general location of the site. Later, these general locations were visited again and perpendicular transects (in the shape of an ' $L$ ') were set up (typically with pink/black flagging). At this time, more intensive sampling occurred, and $1 \mathrm{~m}^{2}$ plots used to describe vegetation were placed along the transects, $10 \mathrm{~m}$ apart. Directions and GPS coordinates are provided for each sample site, but not each plot.

\section{TFSB (Survey Line Burn)}

Cores taken during site reconnaissance by helicopter in May 2002 were located at approximately lat $64.6480^{\circ} \mathrm{N}$., long $148.2958^{\circ} \mathrm{W}$. (NAD27 Alaska datum). All other cores were taken at the long-term location. This site was accessed by boat from the Tanana River. The boat was parked at approximately lat $64.64913^{\circ} \mathrm{N}$., long $148.29828^{\circ} \mathrm{W}$. (NAD83 datum). From there a GPS instrument was used to navigate to approximately lat $64.64913^{\circ} \mathrm{N}$., long $148.29828^{\circ} \mathrm{W}$. (WGS84 datum; see footnote on page 4). This location was the junction of the two transects, along which vegetation plots were placed every $10 \mathrm{~m}$. Soil samples were taken from one of the four corners of each vegetation plot (profiles numbers greater than or equal to eight and divisible by four). The other three corners of the moss plots were described without sampling (see the Tanana_Transects file). Transects to measure woody debris and stand density were located along either side of the soil-sampling transects.

\section{TFSC (Survey Line Control)}

One core was taken during site reconnaissance (May 2002) and was obtained at approximately lat $64.6964^{\circ} \mathrm{N}$., long $148.3205^{\circ} \mathrm{W}$. (NAD27 Alaska datum). All other cores were taken at the longterm TFSC site. Directions to this site are as follows: with mileage based on setting the odometer to zero at Airport Rd. on the Parks Highway, continue on the Parks Highway for 17.8 miles; turn left into the Long-Term Ecological Research (LTER) site (a dirt road); stay on the main road until 22.4 miles; take the left fork in the road; at 22.7 miles, turn right; at 23.1 miles the road splits again and the left fork continues to the river, veer right; park at approximately lat $64.69918^{\circ} \mathrm{N}$., long $148.33193^{\circ} \mathrm{W}$. (NAD83 datum); use a GPS instrument to navigate to approximately lat $64.69744^{\circ} \mathrm{N}$., long $148.31917^{\circ} \mathrm{W}$. (NAD83 datum). This area is the site of other LTER research projects, so there may be established trails that will get you close to this location.

The GPS location noted above was taken at the junction of the two sampling transects. Vegetation plots were located along the transects every $10 \mathrm{~m}$. Samples were taken from one corner of the plots. Along one transect these plots were located within 2-3 m of flux chambers already set up within the site (Wickland and others, 2010; Wickland and others, 2006). Transects to measure woody debris and stand density were located along either side of the soil-sampling transects. 


\section{Appendix 2. Tanana File Description}

The following section contains brief descriptions of the data within the files associated with this report. These files are available at http://pubs.usgs.gov/of/2014/1049/. Unavailable or inapplicable data are indicated by a dash (-). Additional information on these sites, as well as sampling and analyses, are presented in the main report.

\section{Tanana_Physical}

This file contains physical descriptions of the samples, such as volumetric field moisture, bulk density, and particle size.

\begin{tabular}{|c|c|}
\hline Sample ID & $\begin{array}{l}\text { Sample identification: The first four characters indicate the site sampled. The } \\
\text { number that follows these four characters indicates the soil profile within the } \\
\text { site. A decimal point separates the profile number from the basal depth of the } \\
\text { sample (in cm). }\end{array}$ \\
\hline Depth & Indicates the basal depth, in cm, of the sampling increment. \\
\hline $\begin{array}{l}\text { Field horizon } \\
\text { code }\end{array}$ & $\begin{array}{l}\text { Horizon type of the sample, as defined in the field. L, live moss; D, dead moss; } \\
\text { F, fibric organic matter (OM); M, mesic OM; H, humic OM; A, A mineral soil } \\
\text { horizon; B, B mineral soil horizon; C, C mineral soil horizon; LT, litter; Se, } \\
\text { sedge; WD, wood. A lower case 'b' before a horizon code indicates the sample } \\
\text { showed evidence of burning (for example, scorched, charred). A lower case 'f' } \\
\text { before a horizon code indicates the sample was frozen at the time of sampling. }\end{array}$ \\
\hline $\begin{array}{l}\text { Sample } \\
\text { description }\end{array}$ & A brief description of the sample. \\
\hline Date sampled & Date the sample was taken (month/day/year). \\
\hline Thickness & Thickness of the soil horizon $(\mathrm{cm})$. \\
\hline $\begin{array}{l}>2 \mathrm{~mm} \text { in } \\
\text { sample }\end{array}$ & $\begin{array}{l}\text { Dry weight percentage (\%) of soil particles not passing through a } 2 \mathrm{~mm} \text { sieve } \\
\text { after gentle crushing. }\end{array}$ \\
\hline $\begin{array}{l}>1 \mathrm{~cm} \text { in } \\
\text { sample }\end{array}$ & Dry weight percentage (\%) of roots larger than $1 \mathrm{~cm}$ in diameter in the sample. \\
\hline $\begin{array}{l}\text { Bulk density } \\
(<2 \mathrm{~mm})\end{array}$ & $\begin{array}{l}\text { Grams of oven-dried soil per cubic centimeter. Calculated by subtracting the } \\
\text { weight of the soil particles greater than } 2 \mathrm{~mm} \text { and roots greater than } 1 \mathrm{~cm} \\
\text { diameter from the total bulk density (see next column). No volume adjustment } \\
\text { has been made for the fractions removed. }\end{array}$ \\
\hline $\begin{array}{l}\text { Total bulk } \\
\text { density }\end{array}$ & $\begin{array}{l}\text { Grams of oven-dried soil per cubic centimeter for the entire soil sample with no } \\
\text { fractions excluded. }\end{array}$ \\
\hline $\begin{array}{l}\text { Vol. Fld. } \\
\text { Moisture }\end{array}$ & Volumetric Field Moisture: the percentage of water in the sample, by volume. \\
\hline $\begin{array}{l}\text { Convert from } \\
\text { AD to OD }\end{array}$ & $\begin{array}{l}\text { Percentage, by weight, of moisture remaining in a sample after air-drying to } \\
\text { constant weight as determined by oven-drying the sample. These data can be } \\
\text { used to convert carbon and nitrogen content from an oven-dry to an air-dry } \\
\text { basis using by the following equation: } \\
\text { Bulk Density }{ }_{\text {air-dry }}=\text { Bulk Density }_{\text {oven dry }} /\left(1-\left(\text { Covert }_{\mathrm{AD} \text { to } \mathrm{OD}} / 100\right)\right)\end{array}$ \\
\hline Sand & $\begin{array}{l}\text { Percentage, by weight of soil particles greater than } 0.05 \mathrm{~mm} \text { in the sample } \\
\text { remaining after removal of particles greater than } 2 \mathrm{~mm} \text { and roots greater than } 1 \\
\text { cm diameter. }\end{array}$ \\
\hline
\end{tabular}




\begin{tabular}{|l|l|}
\hline Coarse silt & $\begin{array}{l}\text { Percentage, by weight, of soil particles ranging in size from } 0.02 \text { to } 0.05 \mathrm{~mm} \text { in } \\
\text { the sample remaining after removal of particles greater than } 2 \mathrm{~mm} \text { and roots } \\
\text { greater than } 1 \mathrm{~cm} \text { diameter. }\end{array}$ \\
\hline Fine silt & $\begin{array}{l}\text { Percentage, by weight, of soil particles ranging in size from } 0.002 \text { to } 0.020 \mathrm{~mm} \\
\text { in the sample remaining after removal of particles greater than } 2 \mathrm{~mm} \text { and roots } \\
\text { greater than } 1 \mathrm{~cm} \text { diameter. }\end{array}$ \\
\hline Clay & $\begin{array}{l}\text { Percentage, by weight, of soil particles less than } 0.002 \mathrm{~mm} \text { in the sample } \\
\text { remaining after removal of particles greater than } 2 \mathrm{~mm} \text { and roots greater than } 1 \\
\text { cm diameter. }\end{array}$ \\
\hline Notes & $\begin{array}{l}\text { OM+ indicates that residual organic matter in the sample may have skewed } \\
\text { particle-size results toward increased sand and (or) coarse silt; OM indicates } \\
\text { residual organic matter in sample, but likely not enough to skew particle-size } \\
\text { results. }\end{array}$ \\
\hline
\end{tabular}

\section{Tanana_Chemistry}

This file contains $\mathrm{C}, \mathrm{N}, \delta^{13} \mathrm{C}$, and elemental analysis measurements for samples on which these analyses were run.

\begin{tabular}{|l|l|}
\hline Sample ID & $\begin{array}{l}\text { Sample identification: The first four characters indicate the site sampled. } \\
\text { The number that follows these four characters indicates the soil profile } \\
\text { within the site. A decimal point separates the profile number from the basal } \\
\text { depth of the sample (in cm). }\end{array}$ \\
\hline Basal depth & $\begin{array}{l}\text { Indicates the basal depth, in cm, of the sampling increment. } \\
\text { morizon type of the sample, as defined in the field. L, live moss; D, dead } \\
\text { mineral soil horganic matter (OM); M, mesic OM, H, humic OM; A, A } \\
\text { LT, litter; Se, sedge; WD, wood. A lower case 'b' before a horizon code } \\
\text { indicates the sample showed evidence of burning (for example, scorched, } \\
\text { charred). A lower case 'f' before a horizon code indicates the sample was } \\
\text { frozen at the time of sampling. }\end{array}$ \\
\hline coeld horizon & A brief description of the sample. \\
\hline $\begin{array}{l}\text { Sample } \\
\text { description }\end{array}$ & $\begin{array}{l}\text { Percentage, by weight, of carbon in an oven-dried soil sample with } \\
\text { material greater than } 2 \text { mm or } 1 \text { cm diameter removed. }\end{array}$ \\
\hline$\% \mathrm{C}$ & $\begin{array}{l}\text { Percentage, by weight, of nitrogen in an oven-dried soil sample with } \\
\text { material greater than } 2 \text { mm or } 1 \text { cm diameter removed. }\end{array}$ \\
\hline$\% \mathrm{~N}$ & Per mil (\%) value of $\delta^{13} \mathrm{C}$ relative to Pee Dee Belemnite. \\
\hline$\delta^{13} \mathrm{C}$ & $\begin{array}{l}\text { Percentage, by weight, of aluminum in a soil sample with material greater } \\
\text { than } 2 \text { mm or } 1 \text { cm diameter removed. }\end{array}$ \\
\hline $\mathrm{Al}$ & $\begin{array}{l}\text { Percentage, by weight, of calcium in a soil sample with material greater } \\
\text { than } 2 \text { mm or } 1 \text { cm diameter removed. }\end{array}$ \\
\hline $\mathrm{Ca}$ & $\begin{array}{l}\text { Percentage, by weight, of iron in a soil sample with material greater than } 2 \\
\text { mm or } 1 \text { cm diameter removed. }\end{array}$ \\
\hline Fe & $\begin{array}{l}\text { Percentage, by weight, of potassium in a soil sample with material greater } \\
\text { than } 2 \text { mm or } 1 \text { cm diameter removed. }\end{array}$ \\
\hline $\mathrm{K}$ &
\end{tabular}




\begin{tabular}{|c|c|}
\hline $\mathrm{Mg}$ & $\begin{array}{l}\text { Percentage, by weight, of magnesium in a soil sample with material greater } \\
\text { than } 2 \mathrm{~mm} \text { or } 1 \mathrm{~cm} \text { diameter removed. }\end{array}$ \\
\hline $\mathrm{Na}$ & $\begin{array}{l}\text { Percentage, by weight, of sodium in a soil sample with material greater } \\
\text { than } 2 \mathrm{~mm} \text { or } 1 \mathrm{~cm} \text { diameter removed. }\end{array}$ \\
\hline$P$ & $\begin{array}{l}\text { Percentage, by weight, of phosphorus in a soil sample with material greater } \\
\text { than } 2 \mathrm{~mm} \text { or } 1 \mathrm{~cm} \text { diameter removed. }\end{array}$ \\
\hline $\mathrm{Ti}$ & $\begin{array}{l}\text { Percentage, by weight, of titanium in a soil sample with material greater } \\
\text { than } 2 \mathrm{~mm} \text { or } 1 \mathrm{~cm} \text { diameter removed. }\end{array}$ \\
\hline $\mathrm{Ag}$ & $\begin{array}{l}\text { Parts per million of silver in a soil sample with material greater than } 2 \mathrm{~mm} \\
\text { or } 1 \mathrm{~cm} \text { diameter removed. }\end{array}$ \\
\hline As & $\begin{array}{l}\text { Parts per million of arsenic in a soil sample with material greater than } 2 \\
\mathrm{~mm} \text { or } 1 \mathrm{~cm} \text { diameter removed. }\end{array}$ \\
\hline $\mathrm{Au}$ & $\begin{array}{l}\text { Parts per million of gold in a soil sample with material greater than } 2 \mathrm{~mm} \\
\text { or } 1 \mathrm{~cm} \text { diameter removed. }\end{array}$ \\
\hline $\mathrm{Ba}$ & $\begin{array}{l}\text { Parts per million of barium in a soil sample with material greater than } 2 \\
\mathrm{~mm} \text { or } 1 \mathrm{~cm} \text { diameter removed. }\end{array}$ \\
\hline $\mathrm{Bi}$ & $\begin{array}{l}\text { Parts per million of bismuth in a soil sample with material greater than } 2 \\
\mathrm{~mm} \text { or } 1 \mathrm{~cm} \text { diameter removed. }\end{array}$ \\
\hline $\mathrm{Cd}$ & $\begin{array}{l}\text { Parts per million of cadmium in a soil sample with material greater than } 2 \\
\text { mm or } 1 \mathrm{~cm} \text { diameter removed. }\end{array}$ \\
\hline Ce & $\begin{array}{l}\text { Parts per million of cerium in a soil sample with material greater than } 2 \\
\mathrm{~mm} \text { or } 1 \mathrm{~cm} \text { diameter removed. }\end{array}$ \\
\hline Co & $\begin{array}{l}\text { Parts per million of cobalt in a soil sample with material greater than } 2 \mathrm{~mm} \\
\text { or } 1 \mathrm{~cm} \text { diameter removed. }\end{array}$ \\
\hline $\mathrm{Cr}$ & $\begin{array}{l}\text { Parts per million of chromium in a soil sample with material greater than } 2 \\
\mathrm{~mm} \text { or } 1 \mathrm{~cm} \text { diameter removed. }\end{array}$ \\
\hline $\mathrm{Cu}$ & $\begin{array}{l}\text { Parts per million of copper in a soil sample with material greater than } 2 \\
\mathrm{~mm} \text { or } 1 \mathrm{~cm} \text { diameter removed. }\end{array}$ \\
\hline $\mathrm{Eu}$ & $\begin{array}{l}\text { Parts per million of europium in a soil sample with material greater than } 2 \\
\mathrm{~mm} \text { or } 1 \mathrm{~cm} \text { diameter removed. }\end{array}$ \\
\hline $\mathrm{Ga}$ & $\begin{array}{l}\text { Parts per million of gallium in a soil sample with material greater than } 2 \\
\mathrm{~mm} \text { or } 1 \mathrm{~cm} \text { diameter removed. }\end{array}$ \\
\hline Ho & $\begin{array}{l}\text { Parts per million of holmium in a soil sample with material greater than } 2 \\
\text { mm or } 1 \mathrm{~cm} \text { diameter removed. }\end{array}$ \\
\hline $\mathrm{La}$ & $\begin{array}{l}\text { Parts per million of lanthanum in a soil sample with material greater than } 2 \\
\text { mm or } 1 \mathrm{~cm} \text { diameter removed. }\end{array}$ \\
\hline $\mathrm{Li}$ & $\begin{array}{l}\text { Parts per million of lithium in a soil sample with material greater than } 2 \\
\mathrm{~mm} \text { or } 1 \mathrm{~cm} \text { diameter removed. }\end{array}$ \\
\hline $\mathrm{Mn}$ & $\begin{array}{l}\text { Parts per million of manganese in a soil sample with material greater than } 2 \\
\mathrm{~mm} \text { or } 1 \mathrm{~cm} \text { diameter removed. }\end{array}$ \\
\hline Mo & $\begin{array}{l}\text { Parts per million of molybdenum in a soil sample with material greater } \\
\text { than } 2 \mathrm{~mm} \text { or } 1 \mathrm{~cm} \text { diameter removed. }\end{array}$ \\
\hline $\mathrm{Nb}$ & $\begin{array}{l}\text { Parts per million of niobium in a soil sample with material greater than } 2 \\
\text { mm or } 1 \mathrm{~cm} \text { diameter removed. }\end{array}$ \\
\hline $\mathrm{Nd}$ & $\begin{array}{l}\text { Parts per million of neodymium in a soil sample with material greater than } \\
2 \mathrm{~mm} \text { or } 1 \mathrm{~cm} \text { diameter removed. }\end{array}$ \\
\hline
\end{tabular}




\begin{tabular}{|l|l|}
\hline $\mathrm{Ni}$ & $\begin{array}{l}\text { Parts per million of nickel in a soil sample with material greater than } 2 \mathrm{~mm} \\
\text { or } 1 \mathrm{~cm} \text { diameter removed. } \\
\text { Parts per million of lead in a soil sample with material greater than } 2 \mathrm{~mm} \\
\text { or } 1 \mathrm{~cm} \text { diameter removed. }\end{array}$ \\
\hline $\mathrm{Pb}$ & $\begin{array}{l}\text { Parts per million of scandium in a soil sample with material greater than } 2 \\
\text { mm or } 1 \mathrm{~cm} \text { diameter removed. }\end{array}$ \\
\hline $\mathrm{Sc}$ & $\begin{array}{l}\text { Parts per million of tin in a soil sample with material greater than } 2 \mathrm{~mm} \text { or } \\
1 \mathrm{~cm} \text { diameter removed. }\end{array}$ \\
\hline $\mathrm{Sn}$ & $\begin{array}{l}\text { Parts per million of strontium in a soil sample with material greater than } 2 \\
\text { mm or } 1 \mathrm{~cm} \text { diameter removed. }\end{array}$ \\
\hline $\mathrm{Sr}$ & $\begin{array}{l}\text { Parts per million of tantalum in a soil sample with material greater than } 2 \\
\text { mm or } 1 \mathrm{~cm} \text { diameter removed. }\end{array}$ \\
\hline $\mathrm{Th}$ & $\begin{array}{l}\text { Parts per million of thorium in a soil sample with material greater than } 2 \\
\text { mm or } 1 \mathrm{~cm} \text { diameter removed. }\end{array}$ \\
\hline $\mathrm{U}$ & $\begin{array}{l}\text { Parts per million of uranium in a soil sample with material greater than } 2 \\
\text { mm or } 1 \mathrm{~cm} \text { diameter removed. }\end{array}$ \\
\hline $\mathrm{V}$ & $\begin{array}{l}\text { Parts per million of vanadium in a soil sample with material greater than } 2 \\
\text { mm or } 1 \mathrm{~cm} \text { diameter removed. }\end{array}$ \\
\hline $\mathrm{Y}$ & $\begin{array}{l}\text { Parts per million of yttrium in a soil sample with material greater than } 2 \\
\text { mm or } 1 \mathrm{~cm} \text { diameter removed. }\end{array}$ \\
\hline $\mathrm{Yb}$ & $\begin{array}{l}\text { Parts per million of ytterbium in a soil sample with material greater than } 2 \\
\text { mm or } 1 \mathrm{~cm} \text { diameter removed. }\end{array}$ \\
\hline $\mathrm{Zn}$ & $\begin{array}{l}\text { Parts per million of zinc in a soil sample with material greater than } 2 \mathrm{~mm} \\
\text { or } 1 \mathrm{~cm} \text { diameter removed. }\end{array}$ \\
\hline
\end{tabular}

\section{Tanana_Field}

This file contains the field descriptions of sampled soil profiles. (Descriptions of soil profiles which were not sampled, and only described in the field, can be found in the Tanana_Transects file.)

\begin{tabular}{|c|c|}
\hline Sample ID & $\begin{array}{l}\text { Sample identification: The first four characters indicate the site sampled. The } \\
\text { number that follows these four characters indicates the soil profile within the } \\
\text { site. A decimal point separates the profile number from the basal depth of the } \\
\text { sample (in cm). }\end{array}$ \\
\hline Basal depth & Indicates the basal depth, in $\mathrm{cm}$, of the sampling increment. \\
\hline $\begin{array}{l}\text { Field horizon } \\
\text { code }\end{array}$ & $\begin{array}{l}\text { Horizon type of the sample, as defined in the field. L, live moss; D, dead } \\
\text { moss; F, fibric organic matter (OM); M, mesic OM; H, humic OM; A, A } \\
\text { mineral soil horizon; B, B mineral soil horizon; C, C mineral soil horizon; LT, } \\
\text { litter; Se, sedge; WD, wood. A lower case 'b' before a horizon code indicates } \\
\text { the sample showed evidence of burning (for example scorched, charred). A } \\
\text { lower case ' } \mathrm{f} \text { ' before a horizon code indicates the sample was frozen at the } \\
\text { time of sampling. }\end{array}$ \\
\hline $\begin{array}{l}\text { Sample } \\
\text { description }\end{array}$ & A brief description of the sample. \\
\hline Roots & Root abundance and size using conventions of USDA-ARS (Staff, 1998). \\
\hline
\end{tabular}




\begin{tabular}{|l|l|}
\hline Lab pH & The pH of the sample, determined in the lab, by using a LaMotte pH kit. \\
\hline $\begin{array}{l}\text { Moist Munsell } \\
\text { color }\end{array}$ & $\begin{array}{l}\text { Color of moist soil based on the Munsell soil color chart. If the word dry is } \\
\text { written after the color then the color was identified dry (not moist). }\end{array}$ \\
\hline $\begin{array}{l}\text { Von Post or } \\
\text { Texture class }\end{array}$ & $\begin{array}{l}\text { If organic soil, the classification was made by using the von Post scale of } \\
\text { humification (Damman and French, 1987). If mineral soil, the soil-texture } \\
\text { was determined by following conventions of the USDA-ARS (Staff, 1998). }\end{array}$ \\
\hline Plasticity & $\begin{array}{l}\text { Plasticity was determined following the conventions of the USDA-ARS } \\
\text { (Staff, 1998). }\end{array}$ \\
\hline Stickiness & $\begin{array}{l}\text { Stickiness was determined following the conventions of the USDA-ARS } \\
\text { (Staff, 1998). }\end{array}$ \\
\hline Firmness & $\begin{array}{l}\text { Moist consistence was determined following the conventions of the USDA- } \\
\text { ARS (Staff, 1998). }\end{array}$ \\
\hline Structure & $\begin{array}{l}\text { Grade, size, strength, and type of soil structure were determined following the } \\
\text { conventions of the USDA-ARS (Staff, 1998). }\end{array}$ \\
\hline $\begin{array}{l}\text { Height above } \\
\text { mineral }\end{array}$ & $\begin{array}{l}\text { Height of each basal depth above the mineral-soil boundary; therefore, the } \\
\text { bottom organic layer is at zero and all mineral horizons are negative numbers. }\end{array}$ \\
\hline
\end{tabular}

\section{Tanana_Transects}

This file contains descriptions of the soil profiles that were not sampled, but were described in the field.

\begin{tabular}{|c|c|}
\hline Sample ID & $\begin{array}{l}\text { Sample identification: The first four characters indicate the site sampled. The } \\
\text { number that follows these four characters indicates the soil profile within the } \\
\text { site. A decimal point separates the profile number from the basal depth of the } \\
\text { sample (in } \mathrm{cm} \text { ). }\end{array}$ \\
\hline Basal depth & Indicates the basal depth, in cm, of sampling increment. \\
\hline $\begin{array}{l}\text { Field horizon } \\
\text { code }\end{array}$ & $\begin{array}{l}\text { Horizon type of the sample, as defined in the field. L, live moss; D, dead } \\
\text { moss; F, fibric organic matter (OM); M, mesic OM; H, humic OM; A, A } \\
\text { mineral soil horizon; B, B mineral soil horizon; C, C mineral soil horizon; LT, } \\
\text { litter; Se, sedge; WD, wood. A lower case 'b' before a horizon code indicates } \\
\text { the sample showed evidence of burning (for example scorched, charred). A } \\
\text { lower case 'f' before a horizon code indicates the sample was frozen at the } \\
\text { time of sampling. }\end{array}$ \\
\hline $\begin{array}{l}\text { Sample } \\
\text { description }\end{array}$ & A brief description of the sample. \\
\hline Plot description & $\begin{array}{l}\text { Information regarding where the profile was along the transect, who did the } \\
\text { description, the date it was described, and the depth of any water and } \\
\text { permafrost found. }\end{array}$ \\
\hline Roots & $\begin{array}{l}\text { Root abundance and size determined by using conventions of the USDA-ARS } \\
\text { (Staff, 1998). }\end{array}$ \\
\hline $\begin{array}{l}\text { Moist Munsell } \\
\text { color }\end{array}$ & $\begin{array}{l}\text { Color of moist soil based on the Munsell soil color chart. If the word dry is } \\
\text { written after the color, then the color was identified dry (not moist). }\end{array}$ \\
\hline $\begin{array}{l}\text { Von Post or } \\
\text { texture }\end{array}$ & $\begin{array}{l}\text { If organic soil, the classification was made by using the von Post scale of } \\
\text { humification (Damman and French, 1987). If mineral soil, the soil-texture } \\
\text { was determined by following conventions of the USDA-ARS (Staff, 1998). }\end{array}$ \\
\hline Plasticity & Plasticity was determined following the conventions of the USDA-ARS \\
\hline
\end{tabular}




\begin{tabular}{|l|l|}
\hline Stickiness & $\begin{array}{l}\text { (Staff, 1998). } \\
\text { Stickiness was determined following the conventions of the USDA-ARS } \\
\text { (Staff, 1998). }\end{array}$ \\
\hline Firmness & $\begin{array}{l}\text { Moist consistence was determined following the conventions of the USDA- } \\
\text { ARS (Staff, 1998). }\end{array}$ \\
\hline Structure & $\begin{array}{l}\text { Grade, size, strength, and type of soil structure were determined following the } \\
\text { conventions of the USDA-ARS (Staff, 1998). }\end{array}$ \\
\hline $\begin{array}{l}\text { Height above } \\
\text { mineral }\end{array}$ & $\begin{array}{l}\text { Height of each basal depth above the mineral soil-boundary; therefore, the } \\
\text { bottom organic layer is at zero and all mineral horizons are negative numbers. }\end{array}$ \\
\hline
\end{tabular}

\section{Tanana_Understory}

This file contains cover values percentages for different understory species found around the TFSB plots.

\begin{tabular}{|l|l|}
\hline Plot ID & $\begin{array}{l}\text { Where the plot was located, based on the distance from the junction of the two } \\
\text { transect and the general direction the transect traveled. These are the same } \\
\text { locations where soil samples/descriptions occurred. }\end{array}$ \\
\hline $\begin{array}{l}\text { Betula } \\
\text { nana }\end{array}$ & Percentage cover range of Betula nana. \\
\hline $\begin{array}{l}\text { Calamagrostis } \\
\text { canadensis }\end{array}$ & Percentage cover range of Calamagrostis canadensis. \\
\hline $\begin{array}{l}\text { Chamaedaphne } \\
\text { calyculata }\end{array}$ & Percentage cover range of Chamaedaphne calyculata. \\
\hline $\begin{array}{l}\text { Corydalis } \\
\text { sempervirens }\end{array}$ & Percentage cover range of Corydalis sempervirens. \\
\hline $\begin{array}{l}\text { Ditrichum } \\
\text { sp. }\end{array}$ & Percentage cover range of Ditrichum sp. \\
\hline $\begin{array}{l}\text { Epilobium } \\
\text { angustifolium }\end{array}$ & Percentage cover range of Epilobium angustifolium. \\
\hline $\begin{array}{l}\text { Eriophorum } \\
\text { vaginatum }\end{array}$ & Percentage cover range of Eriophorum vaginatum. \\
\hline $\begin{array}{l}\text { Ledum } \\
\text { groendlandicum }\end{array}$ & Percentage cover range of Ledum groendlandicum. \\
\hline $\begin{array}{l}\text { Luzula } \\
\text { rufescens }\end{array}$ & Percentage cover range of Luzula rufescens. \\
\hline $\begin{array}{l}\text { Marchantia } \\
\text { polymorpha }\end{array}$ & Percentage cover range of Marchantia polymorpha. \\
\hline $\begin{array}{l}\text { Stellaria longipes } \\
\text { (?) }\end{array}$ & $\begin{array}{l}\text { Percentage cover range of Stellaria sp., what is thought to be Stellaria } \\
\text { longipes. }\end{array}$ \\
\hline $\begin{array}{l}\text { Picea mariana } \\
\text { seedlings) }\end{array}$ & Percentage cover range of Picea mariana seedlings. \\
\hline
\end{tabular}




\begin{tabular}{|l|l|}
\hline $\begin{array}{l}\text { Polemonium } \\
\text { acutiflorum }\end{array}$ & Percentage cover range of Polemonium acutiflorum. \\
\hline $\begin{array}{l}\text { Polytrichum } \\
\text { juniperinum }\end{array}$ & Percentage cover range of Polytrichum juniperinum. \\
\hline $\begin{array}{l}\text { Salix } \\
\text { sp. }\end{array}$ & Percentages cover range of Salix sp. \\
\hline Unkown & Percentages cover range of unknown vegetation. \\
\hline $\begin{array}{l}\text { Vaccinium } \\
\text { uligonosum }\end{array}$ & Percentages cover range of Vaccinium uligonosum. \\
\hline $\begin{array}{l}\text { Vaccinium vitis- } \\
\text { idaea }\end{array}$ & Percentages cover range of Vaccinium vitis-idaea. \\
\hline
\end{tabular}

\section{Tanana_Density}

This file contains data pertaining to tree-stand density. There are four worksheets in this file: 2-m plot data for each site and point-center quarter (PCQ) data for each site. The column heading for the 2-m plot data are as follows:

\begin{tabular}{|l|l|}
\hline Site & The plot number (sequentially assigned) where the data were taken. \\
\hline Species & Tree species found (BS, black spruce; TA, tamarack) \\
\hline DBH & $\begin{array}{l}\text { The diameter (cm) of the tree taken at breast height }(1.37 \mathrm{~m}) \text {. A dash indicates } \\
\text { that the tree was shorter than } 1.37 \mathrm{~m} .\end{array}$ \\
\hline Diam at base & The diameter (cm) at the base of the tree. \\
\hline Ht to live & $\begin{array}{l}\text { The height }(\mathrm{m}) \text { to the live portion of the tree. This value, in relation to the } \\
\text { height to crown (next column), gives an idea of tree health. }\end{array}$ \\
\hline Ht to crown & The height $(\mathrm{m})$ to the crown of the tree. \\
\hline Condition & The condition of the tree: $\mathrm{L}$, live; $\mathrm{D}$, dead; , dead snag. \\
\hline Notes & Notes regarding the condition of the tree or measurements. \\
\hline
\end{tabular}

The column headings for the PCQ data are as follows:

\begin{tabular}{|c|c|}
\hline Location & The plot number (sequentially assigned) where the data were taken. \\
\hline Tree & Tree number (1-4) \\
\hline Species & Tree species found (BS, black spruce; TA, tamarack) \\
\hline DBH & $\begin{array}{l}\text { The diameter }(\mathrm{cm}) \text { of the tree taken at breast height }(1.37 \mathrm{~m}) \text {. A dash indicates } \\
\text { that the tree was shorter than } 1.37 \mathrm{~m} \text {. }\end{array}$ \\
\hline Diam at base & The diameter $(\mathrm{cm})$ at the base of the tree. \\
\hline Ht to live & $\begin{array}{l}\text { The height (m) to the live portion of the tree. This value, in relation to the } \\
\text { height to crown (next column), gives an idea of tree health. }\end{array}$ \\
\hline Ht to crown & The height $(\mathrm{m})$ to the crown of the tree. \\
\hline Distance & Distance (m) from the center point to the tree. \\
\hline Condition & The condition of the tree: L, live; D, dead; S, dead snag. \\
\hline Avg Dist & Average distance for all four trees at a point. \\
\hline
\end{tabular}




\begin{tabular}{|l|l|}
\hline Mean area & $\begin{array}{l}\text { Mean area taken up by the trees measured, as described by Cottam and Curtis } \\
\text { (1956), where the average distance is divided by a correction factor (0.50 for } \\
\text { one tree, } 0.66 \text { for two trees, } 0.81 \text { for three trees, and } 1.00 \text { for four trees), and } \\
\text { this value is squared. }\end{array}$ \\
\hline Density & $\begin{array}{l}\text { Density (trees/hectare) for the trees found at the point, as described by Cottam } \\
\text { and Curtis (1956), where density is the 1/Mean Area. This value is multiplied } \\
\text { by 10,000 to convert from meters to hectares. }\end{array}$ \\
\hline Notes & Notes regarding the condition of the tree or measurements. \\
\hline
\end{tabular}

\section{Tanana_Woody_Debris}

This file contains data pertaining to the woody-debris measurements. There are five worksheets in this file. The two worksheets with the data for fine woody debris are labeled TFSC $<7$ and TFSB $<7$ and follow this format:

\begin{tabular}{|c|c|}
\hline Site & Transect number measured. \\
\hline Type & $\begin{array}{l}\text { Above, aboveground woody debris, }<50 \% \text { covered by organic soil; roots } \\
\text { above, tree root }<50 \% \text { covered by organic material; below, belowground } \\
\text { woody debris, } 50-99 \% \text { covered by organic soil; roots below, tree root } 50-99 \% \\
\text { covered by organic soil. }\end{array}$ \\
\hline Size class & $\begin{array}{l}\text { The diameter }(\mathrm{cm}) \text { of fine woody debris is classified into one of several size } \\
\text { classes: } 1 \text { is } 0.0-0.49 \mathrm{~cm} \text {; } 2 \text { is } 0.50-0.99 \mathrm{~cm} ; 3 \text { is } 1.0-2.99 \mathrm{~cm} ; 4 \text { is } 3.0-4.99 \\
\mathrm{~cm} \text {; and } 5 \text { is } 5.0-6.99 \mathrm{~cm} \text {. }\end{array}$ \\
\hline Sect. 1 & Observations found for that size class for section 1 of the transect. \\
\hline Sect. 2 & Observations found for that size class for section 2 of the transect. \\
\hline Sect. 3 & Observations found for that size class for section 3 of the transect. \\
\hline Sect. 4 & Observations found for that size class for section 4 of the transect. \\
\hline All Sect. & The sum of observations for all sections on a transect. \\
\hline Per $1 \mathrm{~m}$ & $\begin{array}{l}\text { The total number of observations for that size class divided by the number of } \\
\text { meters on a transect (usually } 20 \mathrm{~m} \text { ). }\end{array}$ \\
\hline TA Mult. & $\begin{array}{l}\text { Tamarack fuel-load multiplier, which combines the effects of specific gravity, } \\
\text { the tilt angle of the woody debris, and the mean squared diameter on the } \\
\text { conversion of the number of intercepts to fuel load (see Nalder and others, } \\
\text { 1999; this value is taken from table } 6 \text { for the Central Saskatchewan region, for } \\
\text { the appropriate size class). }\end{array}$ \\
\hline BS Mult. & $\begin{array}{l}\text { Black spruce multiplier, which combines the effects of specific gravity, the tilt } \\
\text { angle of the woody debris, and the mean squared diameter on the conversion } \\
\text { of the number of intercepts to fuel load (see Nalder and others, 1999; this } \\
\text { value is taken from Table } 6 \text { for the Central Saskatchewan region, for the } \\
\text { appropriate size class). }\end{array}$ \\
\hline$\% \mathrm{TA}$ & $\begin{array}{l}\text { Percentage of the stand that is tamarak, as determined by the point-center- } \\
\text { quarter method. }\end{array}$ \\
\hline$\%$ BS & $\begin{array}{l}\text { Percentage of the stand that is black spruce, as determined by the point-center- } \\
\text { quarter method. }\end{array}$ \\
\hline TA (kg/ha) & Amount of tamarack fine woody debris (kg/ha). \\
\hline BS (kg/ha) & Amount of black spruce fine woody debris (kg/ha). \\
\hline
\end{tabular}




\begin{tabular}{|l|l|}
\hline Total (kg/ha) & Tamarack plus black spruce fine woody debris (kg/ha). \\
\hline All sizes & $\begin{array}{l}\text { Total fine woody debris for that transect (both tree species and all size } \\
\text { classes). }\end{array}$ \\
\hline
\end{tabular}

The worksheet with the data for coarse woody debris is labeled $>7$ All and follows this format:

\begin{tabular}{|c|c|}
\hline Site & Transect number measured. \\
\hline Transect \# & On which transect the coarse wood was measured. \\
\hline \# of sections & Number of sections within that transect. \\
\hline Sp & Species of coarse wood \\
\hline Line \# & Section or line \# (for relocation) \\
\hline Decay class & $\begin{array}{l}\text { The }>7 \text { cm pieces were recorded as one of five decay classes: (1) Bark and } \\
\text { wood intact, knife unable to penetrate samples; (2) wood beginning to get } \\
\text { mealy, still hard for knife to penetrate sample; (3) wood mealy throughout, } \\
\text { knife can penetrate sample somewhat; (4) wood can be broken into pieces, } \\
\text { knife easily penetrates sample; (5) sample no longer holds shape and splits } \\
\text { into small pieces. Debris that was decay classes 1-3 was assumed to be sound. } \\
\text { Debris that was decay classes } 4-5 \text { was assumed to rotten. This cutoff can be } \\
\text { manipulated within the spreadsheet by adjusting the decay class value at } \\
\text { which debris changes to "rotten" (see cell AB4). }\end{array}$ \\
\hline Location & $\begin{array}{l}\text { A, above ground, }<50 \% \text { covered by organic soil; B = belowground, 50-99\% } \\
\text { covered by organic soil. }\end{array}$ \\
\hline Diam $(\mathrm{cm})$ & Diameter (in $\mathrm{cm}$ ) of the coarse wood. \\
\hline $\operatorname{Diam}(\mathrm{m})$ & Calculated by converting previous column to meters. \\
\hline $\operatorname{Diam}^{2}(\mathrm{~m})$ & Calculated by squaring previous column. \\
\hline BS Above sound & $\begin{array}{l}\text { Calculated based on if-then statements. If species, decay class, and location } \\
\text { (above/below) match, the diam }{ }^{2} \text { value gets placed into this column. This value } \\
\left.\text { is summed for each transect (subsequent rows, labeled Sum of diam }{ }^{2}\right) \text { and then } \\
\text { converted to coarse wood inventory }(I, \mathrm{~kg} / \mathrm{ha}) \text { by using the following formula: } \\
\mathrm{I}=\left(\mathrm{G} * 1.234 * \sum\left(\operatorname{diam}^{2}\right)\right) /(\# \text { sections } * 5 \mathrm{~m}) * 1,000 \mathrm{~g} / \mathrm{kg} * 10,000 \mathrm{~m} / \mathrm{ha} \text {, } \\
\text { where } \mathrm{G} \text { is } \mathrm{G} \text { factor }\left(\mathrm{g} / \mathrm{cm}^{3}\right) \text { and } 1.234 \text { is a constant to convert volume to } \\
\mathrm{kg} / \mathrm{m}^{2} \text {. The G factors for sound wood are based on size class } 5 \text { values for each } \\
\text { species for the Southern Northwest Territories (Nalder and others, 1999). See } \\
\text { the description in the Decay column for more information regarding the decay } \\
\text { classes used and the distinction between sound and rotten wood. }\end{array}$ \\
\hline BS Above rotten & $\begin{array}{l}\text { Calculated based on if-then statements. If species, decay class, and location } \\
\text { (above/below) match, the diam }{ }^{2} \text { value gets placed into this column. This value } \\
\left.\text { is summed for each transect (subsequent rows, labeled Sum of diam }{ }^{2}\right) \text { and then } \\
\text { converted to coarse wood inventory }(\mathrm{I}, \mathrm{kg} / \mathrm{ha}) \text { by using the following formula: } \\
\mathrm{I}=\left(\mathrm{G} * 1.234 * \sum\left(\operatorname{diam}^{2}\right)\right) /(\# \text { sections } * 5 \mathrm{~m}) * 1,000 \mathrm{~g} / \mathrm{kg} * 10,000 \mathrm{~m} / \mathrm{ha} \text {, } \\
\text { where } \mathrm{G} \text { is G factor }\left(\mathrm{g} / \mathrm{cm}^{3}\right) \text { and } 1.234 \text { is a constant to convert volume to } \\
\mathrm{kg} / \mathrm{m}^{2} \text {. The G factors for rotten wood are obtained from two samples of } \\
\text { decaying wood from Thompson, Manitoba, based on thoughts that values by } \\
\text { Brown (1974) are too high (M. Harmon, oral commun.). See the description } \\
\text { of the Decay column for more information regarding the decay classes used } \\
\text { and the distinction between sound and rotten wood. }\end{array}$ \\
\hline BS Below & Calculated based on if-then statements. If species, decay class, and location \\
\hline
\end{tabular}




\begin{tabular}{|c|c|}
\hline & $\begin{array}{l}\text { (above/below) match, the diam }{ }^{2} \text { value gets placed into this column. This value } \\
\text { is summed for each transect (subsequent rows, labeled Sum of diam }{ }^{2} \text { ) and then } \\
\text { converted to coarse wood inventory }(I, \mathrm{~kg} / \mathrm{ha}) \text { by using the following formula: } \\
\mathrm{I}=\left(\mathrm{G} * 1.234 * \sum\left(\operatorname{diam}^{2}\right)\right) /(\# \text { sections } 5 \mathrm{~m}) * 1,000 \mathrm{~g} / \mathrm{kg} * 10,000 \mathrm{~m} / \mathrm{ha} \text {, } \\
\text { where } \mathrm{G} \text { is } \mathrm{G} \text { factor }\left(\mathrm{g} / \mathrm{cm}^{3}\right) \text { and } 1.234 \text { is a constant to convert volume to } \\
\mathrm{kg} / \mathrm{m}^{2} \text {. The G factors for sound wood are based on size class } 5 \text { values for each } \\
\text { species for the Southern Northwest Territories (Nalder and others, 1999). See } \\
\text { the description in the Decay column for more information regarding the decay } \\
\text { classes used and the distinction between sound and rotten wood. }\end{array}$ \\
\hline BS Below rotten & $\begin{array}{l}\text { Calculated based on if-then statements. If species, decay class, and location } \\
\text { (above/below) match, the diam }{ }^{2} \text { value gets placed into this column. This value } \\
\left.\text { is summed for each transect (subsequent rows, labeled Sum of diam }{ }^{2}\right) \text { and then } \\
\text { converted to coarse wood inventory }(I, \mathrm{~kg} / \mathrm{ha}) \text { by using the following formula: } \\
\mathrm{I}=\left(\mathrm{G} * 1.234 * \sum\left(\operatorname{diam}^{2}\right)\right) /(\# \text { sections } * 5 \mathrm{~m}) * 1,000 \mathrm{~g} / \mathrm{kg} * 10,000 \mathrm{~m} / \mathrm{ha} \text {, } \\
\text { where } \mathrm{G} \text { is } \mathrm{G} \text { factor }\left(\mathrm{g} / \mathrm{cm}^{3}\right) \text { and } 1.234 \text { is a constant to convert volume to } \\
\mathrm{kg} / \mathrm{m}^{2} \text {. The } \mathrm{G} \text { factors for rotten wood are obtained from two samples of } \\
\text { decaying wood from Thompson, Manitoba, based on thoughts that values by } \\
\text { Brown (1974) are too high (M. Harmon, oral commun.). See the description } \\
\text { of the Decay column for more information regarding the decay classes used } \\
\text { and the distinction between sound and rotten wood. }\end{array}$ \\
\hline TA Above sound & $\begin{array}{l}\text { Calculations for above-ground, sound, tamarack woody debris. See } \\
\text { explanation for BS Above sound for more information. }\end{array}$ \\
\hline TA Above rotten & $\begin{array}{l}\text { Calculations for above-ground, rotten, tamarack woody debris. See } \\
\text { explanation for BS Above rotten for more information. }\end{array}$ \\
\hline TA Below sound & $\begin{array}{l}\text { Calculations for below-ground, sound, tamarack woody debris. See } \\
\text { explanation for BS Below sound for more information. }\end{array}$ \\
\hline TA Below rotten & $\begin{array}{l}\text { Calculations for below-ground, rotten, tamarack woody debris. See } \\
\text { explanation for BS Below rotten for more information. }\end{array}$ \\
\hline $\begin{array}{l}\text { Unknown Above } \\
\text { sound }\end{array}$ & $\begin{array}{l}\text { Calculations for above-ground, sound woody debris of an unknown species. } \\
\text { See explanation for BS Above sound for more information. }\end{array}$ \\
\hline $\begin{array}{l}\text { Unknown Above } \\
\text { rotten }\end{array}$ & $\begin{array}{l}\text { Calculations for above-ground, rotten woody debris of an unknown species. } \\
\text { See explanation for BS Above rotten for more information. }\end{array}$ \\
\hline $\begin{array}{l}\text { Unknown Below } \\
\text { sound }\end{array}$ & $\begin{array}{l}\text { Calculations for below-ground, sound woody debris of an unknown species. } \\
\text { See explanation for BS Below sound for more information. }\end{array}$ \\
\hline $\begin{array}{l}\text { Unknown Below } \\
\text { rotten }\end{array}$ & $\begin{array}{l}\text { Calculations for below-ground, rotten woody debris of an unknown species. } \\
\text { See explanation for BS Below rotten for more information. }\end{array}$ \\
\hline $\begin{array}{l}\text { Above Total } \\
\text { (kg/ha) }\end{array}$ & Total above ground course woody debris (kg/ha). \\
\hline $\begin{array}{l}\text { Below Total } \\
\text { (kg/ha) }\end{array}$ & Total below ground coarse woody debris (kg/ha). \\
\hline All Total (kg/ha) & rse woody debris (kg/ha). \\
\hline
\end{tabular}

